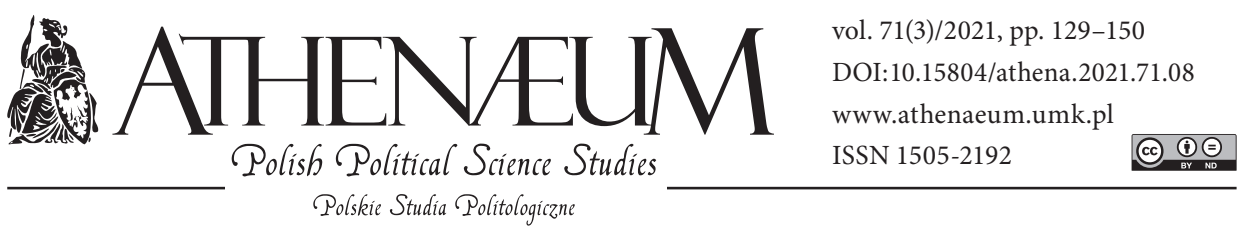

\title{
DETERMINANTS AND IMPLICATIONS OF POLITICAL AND ECONOMIC RELATIONS BETWEEN CHINA AND SOUTH KOREA DURING THE REIGN OF XI JINPING
}

\author{
UWARUNKOWANIA I IMPLIKACJE POLITYCZNO- \\ -GOSPODARCZYCH RELACJI CHIN Z KOREĄ POŁUDNIOWA \\ ZA RZĄDÓW XI JINPINGA
}

Paweł Bielicki*๑

\section{- ABSTRACT}

Przedmiotem mojego zainteresowania jest przedstawienie najważniejszych uwarunkowań i implikacji charakteryzujących relacje chińsko-południowokoreańskie za rządów Xi Jinpinga na płaszczyźnie politycznej i ekonomicznej. Celem moich rozważań będzie opisanie aktualnego stanu rzeczy we wzajemnych stosunkach oraz próba przeanalizowania, jak relacje obu podmiotów będą wpływać na konfigurację międzynarodową systemu bezpieczeństwa na terenie Azji Wschodniej.

$\mathrm{Na}$ wstępie niniejszego studium prześledzę historię wzajemnych relacji za czasów zimnej wojny i proces normalizacji stosunków. Następnie przeanalizuję kontakty na linii Chiny-Republika Korei od 2013 r. i objęcia przez Xi Jinpinga oraz Parka Geun-hye sterów władzy w swoich krajach, skupiając się na najistotniejszym wówczas dla obustronnych związków problemie programu nuklearnego Korei Północnej. Niezwykle ważnym zagadnieniem w niniejszym tekście jest poruszenie
The subject of my interest is the presentation of the most important determinants and implications that characterize Sino-South Korean relations under Xi Jinping. The aim of my considerations will be to describe the current state of affairs in mutual relations and an attempt to analyse how the relations of both entities will affect the international configuration of the security system in East Asia.

At the beginning of this study, I follow the history of mutual relations during the Cold War and the process of normalization of relations. Then I analyse the contacts between China and the Republic of Korea since 2013 and the assumption of power by Xi Jinping and Park Geun-hye in their respective countries, focusing on the problem of the North Korean nuclear program, which was most important at that time for bilateral unions. An extremely important issue mentioned in this text mention is the installation of the United States system THAAD in July 2016,

* Asia and Pacific Society in Toruń. 
kwestii zainstalowania na terenie Korei Południowej amerykańskiego systemu przeciwrakietowego THAAD w lipcu 2016 r., co doprowadziło do pogorszenia się relacji między Chinami a Republiką Korei, gdyż chiński rząd potraktował ten krok jako zagrożenia dla bezpieczeństwa ChRL. Istotnym punktem moich rozważań będzie także znaczenie rywalizacji amerykańsko-chińskiej dla kontaktów między rządami obu omawianych w tekście krajów azjatyckich. W dalszej części opisuję kontakty Pekin-Seul po wybuchu epidemii koronawirusa na przełomie 2019 i 2020 r. Dodatkowo poruszam także problem powiązań ekonomicznych obu państw.

W podsumowaniu chciałbym odpowiedzieć na pytanie, czy w przyszłości należy spodziewać się intensyfikacji stosunków Pekin-Seul. Zamierzam stwierdzić, jak przybierająca na sile rywalizacja na linii Stany Zjednoczone-Chiny może przyczynić się do modyfikacji priorytetów dyplomacji południowokoreańskiej.

Słowa kluczowe: Chiny; Korea Południowa; koronawirus; Moon Dze In; Stany Zjednoczone; Xi Jinping which caused deterioration of relations between China and the Republic of Korea, because the Chinese government treated this step as a threat to the security of the PRC. An important point in my considerations will also be the problem of USChinese rivalry in contacts between the governments of the two Asian countries discussed in the text. Later, I describe the contacts between Beijing and Seoul after the outbreak of the coronavirus epidemic at the turn 2020. In addition, I also mention the problem of economic ties between the two countries.

In conclusion, I would like to answer the question of whether Beijing-Seoul relations should be intensified in the future. I am going to conclude how the escalating US-China rivalry could contribute to modifying the priorities of South Korean diplomacy.

Keywords: China; South Korea; coronavirus; Moon Jae-in; USA; Xi Jinping

\section{INTRODUCTION}

The global processes currently taking place related to the coronavirus pandemic and the growing role of China make us ask about the mutual conditions and dependence of the Middle Kingdom with countries important for the security in East Asia. One of such state entities is South Korea. In this text, I would like to present the bilateral relations between Beijing and Seoul under the rule of the Chinese leader Xi Jinping. I am going to illustrate how their interactions affect the international situation, especially in relation to the Far East. It will also be important to trace the role of the United States in their relations with both sides. The basic research hypothesis is the assumption that the relations of these entities since 2013 have been strictly determined by four problems: the Korean crisis, contacts between the two countries with the United States, the coronavirus epidemic and the dependencies of Beijing and Seoul in relations with other East Asian countries. It will be advisable to ask a few research questions: How were 
the relations between Beijing and Seoul during and immediately after the Cold War? How is the Sino-South Korean relationship affected by the situation on the entire Korean Peninsula? How did the problem of the US installation of the THAAD missile defense system (Terminal High Altitude Area Defense) change the relations? How is increasing US-China rivalry and the COVID-19 pandemic impacting Beijing-Seoul dependency? Finally, how do both of these factors affect South Korea's attitude towards the rest of East Asia? What are the economic connections between the two entities that are of our interest? Qualitative (systemic) analysis was made on the basis of information contained in books, scientific articles and Internet sources in Polish and English.

\section{HISTORY OF SINO-SOUTH KOREAN RELATIONS UNTIL 2013}

In discussing contemporary relations between China and South Korea, we must go back to August 1945, when the Korean Peninsula was divided into the northern and southern parts between the Soviet Union and the United States. In the first part, in September 1948, the Democratic People's Republic of Korea (DPRK) was established. It was headed by Kim Il-sung, a Korean partisan who stayed in the Soviet Union during World War II. In turn, in the south, the farright Korean politician Syngman Rhee (Li Syngman) took power. Significant changes took place in China at that time as well. After many years of civil war between the ruling nationalists led by Chiang Kai-shek and the communists led by Mao Zedong, the latter took power on October 1, 1949, creating the People's Republic of China (PRC). The new Chinese leader from the very beginning of his rule took an anti-Western position and sought to strengthen relations with the Soviet Union. The Korean War and the aggression against South Korea by Kim Il-sung's troops on June 25, 1950 provided an opportunity to achieve this goal. Although Mao treated South Korea as an American satellite and an irrelevant state to China's diplomatic strategy, he nevertheless recognized that, with the US joining the conflict, China's active participation in the Korean War would not only save Kim from collapse, but also contribute to the rise of China in the international arena, it would strengthen personal contacts with the Soviet dictator, Joseph Stalin, and at the same time weaken the United States. Accordingly, in October 1950, he made a decision to send over 400,000 "volunteers" to South Korea (Roszkowski, 2005, p. 40). This step has dramatically worsened ties between Beijing and Seoul. Mutual hostility continued for over 25 years. At that 
time, the two countries did not maintain political and economic ties, as Mao continued to see the South Korean regime as dependent on the United States and did not accept the government's far-right ideology. In addition, the Chinese communists feared that the shift in Beijing's policy might be seen negatively by North Korea, and North Korea might retaliate towards Moscow and pursue a policy hostile to China. China's relations with both Koreas began to change only after the death of Mao Zedong in September 1976 and the coming to power of Deng Xiaoping, a supporter of economic reforms and opening China to the outside world. Although he was still concerned about the reaction of North Korea to possible contacts with Seoul, from the beginning of the 1980s, the leadership of the CPC (Communist Party of China) allowed indirect trade and economic relations with South Korea.

A clear sign of Beijing's readiness to initiate diplomatic ties was the consent of Beijing to the participation of Chinese athletes in the Olympic Games in Seoul in August 1988. This move was positively received by the South Korean side. The initiator of the change in policy towards Beijing was the new president of the country, Roh Tae-woo, who in July of that year started the "northern policy", aimed at, inter alia, probing China in the context of initiating diplomatic relations between the two entities. For the time being, China responded cautiously so as not to inflame relations with Kim (I.J. Kim, 1998, pp. 29-30). Nevertheless, Deng expressed the view that talks should be started, regardless of ideological differences (Dziak \& Bayer, 2006, p. 28). The intentions of the Chinese leader were made more specific as a result of international isolation following the suppression of the Tiananmen Square protests in June 1989, the recognition by the USSR of South Korea in September 1990, the collapse of the Soviet empire, and finally the need to accelerate the economic development of the Middle Kingdom. It was then that the authorities in Beijing decided to establish contacts with South Korea. The decision was finally made in 1991, when South Korea opened a trade office in China in January, which initiated an industry fair in Seoul in May (I.J. Kim, 1998, p. 30). The agreement was finally concluded on August 24, 1992. At that time, relations between China and South Korea were confirmed as "good-neighbourly and friendly cooperation" (Li, 2020, p. 44). Undoubtedly, the Chinese communists sought to develop a certain model of stability and peace on the Korean Peninsula, believing that the growing tensions were not in China's interest. They also believed that the South Korean economic model could contribute to an increase in foreign investment in China (Renner, 2006, p. 10). 
Another solid ground for establishing contacts was the fact that, unlike Japan, the Chinese and Korean people were victims of persecution by the military regime in Tokyo in the first half of the $20^{\text {th }}$ century. It seems that this should explain the words of the Chinese scientist Chu Shulong that China and South Korea are not and will not be antagonistic nations (Yi, 2002, pp. 323-324). It must not be forgotten that the authorities in Beijing counted on increasing the possibility of influencing the USA and Japan (Strnad, 2014, p. 286), and weakening the ties of South Korea with Taiwan, as confirmed by Deng's words that increasing dependence between China and the Republic of Korea (ROK Republic of Korea) is beneficial for China, as it will bring economic profits for China and contribute to the severance of Seoul's relations with Taipei (J.Y. Lee, 2020 , p. 4), which actually happened. Over the following years, the relationships of both entities were characterized by an increase in economic contacts with simultaneous declarations of friendship and cooperation. In this context, the then-presidents of China, Jiang Zemin and South Korea, Kim Dae-jung, stated in a meeting in November 1998 that the two countries were elevating their relationship to the level of "strategic cooperation". The same trend was present in October 2003, when Jiang's successor, Hu Jintao, signed an agreement with the President of South Korea, Roh Moo-hyun, assuming the relationship of both entities as a "comprehensive partnership based on cooperation" (J.Y. Lee, 2020, pp. 5-6). It is worth noting that this one coincided with an improvement in relations between the two Koreas due to the South Korean President's "sunny policy" and his first trip to the DPRK in 2000 and a meeting with Kim Jong-il.

Despite positive declarations, political relations between China and South Korea were still characterized by mutual distrust, based mainly on close cooperation between South Koreans and the United States. It is worth considering that this trend could have been influenced by the policy of Roh's successor, Lee Myung-bak, who was more sympathetic to the US than his predecessor (Snyder \& Byun, 2009, p. 25). Although it may be reasonable to presume that the PRC was not willing to link the intensification of such pro-American stance by the South Korean president to the subsequent nuclear and missile tests by North Korea in 2006-2010, for destabilization of the Far East in the era of the struggle for succession in the DPRK due to the deteriorating health of Kim Jong-il. The role of the Korean problem in the sphere of the present considerations will be analysed below. 


\section{POLITICAL INSTRUMENTS IN CHINA-SOUTH KOREA RELATIONS}

The problem of the North Korean nuclear program has been a key factor determining the mutual relations of the entities of interest to us for a long time. Since the $1990^{\text {s }}$ and the initiation of the 2003 six-party talks by the parties, which included the US, Russia, Japan, North Korea, South Korea, and China, both have sought to get rid of nuclear weapons from North Korea, but for different reasons. The South Korean side considers the communist neighbour's nuclear program a threat to its security. In contrast, Chinese communists believe that nuclear North Korea is an image problem for them in further international expansion and is not conducive to gaining allies by them in the face of a potential confrontation with the United States. The 2013 nuclear test of the regime was accepted with considerable dissatisfaction in Beijing. Although the new secretary general of the Central Committee of the CCP, Xi Jinping, was guided by the continuation of his predecessors' policy on the Korean issue. He believed that further nuclear tests could have negative implications for China. In an attempt to force the new leader of the country, Kim Jong-un, to soften the rhetoric, Xi then decided to tighten ties with the southern part of Korea. This position was confirmed in December 2012 by the words of Chinese Foreign Ministry spokesman Hong Lei, immediately after the election of the new President of the Republic of Korea, Park Geun-hye. The diplomat then expressed the view that both parts of the Peninsula should cooperate with each other in order to further deepen "strategic and political mutual trust" (Snyder \& Byun, 2013, p. 100). The task was easier because Park, the daughter of the former president of the country, Park Chunghee, murdered in October 1979 by the intelligence chief of the Republic of Korea, Kim Jae-kyu (Roszkowski, 2005, p. 271), was more inclined than her predecessors to strengthening contacts with the communist regime in China.

However, the intentions of both sides were quickly put to the test, as shortly after Xi took power, China expanded the Air Defense Identification Zone (East China Sea) over South Korea. In reality, however, this incident did not have a significant impact on the contacts of both sides. Already in June 2013, Park arrived in Beijing, where, after talking with $\mathrm{Xi}$, a number of agreements were signed, including the establishment of a channel of dialogue between the head of the National Security Council (NSC) of South Korea and his Chinese counterpart (Ho, 2018, p. 74). This step was symbolically important as Beijing introduced analogous channels for talks with Washington and Moscow (J.Y. Lee, 2020, p. 9). During the visit of the president, it was also signalled that Beijing and Seoul 
would jointly discuss the issue of the reunification of the Korean Peninsula, which provoked a relatively independent policy from China at that time, and in Pyongyang - understandable fury (Hoshino \& Hiraiwa, 2020, p. 24). It was expressed by the removal from all positions of Jang Song-thaek, Kim Jong-un's uncle, a supporter of close cooperation with Beijing and reforming the North Korean economy along the lines of the Chinese (Fifield, 2020, p. 190).

Meanwhile, the dialogue between both entities continued in the following months. This was confirmed by Xi's visit to South Korea in July 2014. In the negotiations, the leaders of both countries emphasized the need to denuclearize the Korean Peninsula and to accelerate the talks in the trade sphere. The visit was so important that Xi visited Seoul before his visit to North Korea. Park spoke of the "Chinese dream" and the "Korean dream" joined together to create the "Northeast Asia dream" (Jin, 2015, p. 63). Another confirmation of good PRC-ROK relations at the time was the fact that during the celebrations in 2015 commemorating the $70^{\text {th }}$ anniversary of China's victory over Japan in World War II, Park stood next to Xi in Tiananmen Square in Beijing (Mencel, 2018b, p. 45).

However, the situation changed with the announcement by the US and South Korea in mid-2016 of their intention to create a THAAD missile system to be installed by the United States in the southern part of the Peninsula. The American initiative was primarily aimed at increasing the protection of the Republic of Korea against a potential military attack by the DPRK and confirming compliance with allied commitments to Seoul. However, this idea was violently opposed by the Chinese government, which - despite the fact that THAAD was only a response to the subsequent nuclear and missile tests of North Korea demanded that the project be stopped, claiming that it was a threat to the security of the Middle Kingdom (Trzcińska, 2019, p. 68). On July 8, Foreign Ministry spokesman Hong Lei said in response to a press inquiry that the implementation of the system by the US and ROK would in no way help achieve the goal of denuclearization and maintaining peace on the Peninsula. According to the Chinese politician, Seoul's position contradicts the efforts made by all parties to solve the problem through dialogue and consultations, and seriously sabotages the strategic security interests of the countries in the region, including China (Swaine, 2017, p. 4). Since August 1, People's Daily, Global Times, Guangming Daily and CCTV, the mass media supervised by Chinese authorities, harshly criticized South Korea, suggesting that it would be the first to be attacked in the event of a possible war (Ho, 2018, p. 78). 
In order to overcome the discrepancies in this matter, politicians from both countries organized the $\mathrm{Xi}$-Park summit in Hangzhou in eastern China in September of the same year. The president then pointed out again that the deployment of THAAD only serves to contain North Korea's nuclear ambitions, and China's concerns are unfounded. However, $\mathrm{Xi}$ also strongly reiterated his position on the matter, stressing that such moves by South Korea could "intensify the disputes" (J.Y. Lee, 2020, p. 10). Although the negotiations on the BeijingSeoul line were still ongoing, the ambassador of the Republic of Korea to the People's Republic of China, Kim Jang-soo, presented in February 2017 to the deputy chief of Chinese diplomacy Liu Zhenmin the final decision to implement the system. In response, the Chinese Ministry of Defense suspended high-level dialogue with South Korea and postponed the visit of the South Korean minister to China (Swaine, 2017, p. 2).

Beijing' dissatisfaction with the THAAD was also due to the fact that the Chinese communists treated Seoul as a country with a military policy more independent from the United States than Japan. However, they did not pay attention to the fact that the implementation of the THAAD system was reinforced by another DPRK nuclear test in January 2016 and the related concerns of Seoul for the national security of its country (Pietrewicz, 2018). What is remarkably significant, during the Korean crisis of 2016, Beijing did not take advantage of the hotline between defense ministries and politicians from both countries (Pietrewicz, 2020, p. 241). As time passed, the parties finally came to the conclusion that it was unnecessary to further fuel the dispute on this issue. It is worth emphasizing the words of Wang Yi, the Chinese foreign minister, who said that China attached great importance to South Korea's position that THAAD will not have any negative impact on China's security, and that none of the parties needs further widening of the divergence on this matter (Konflikt nie leży..., 2017). Nevertheless, China's politicians and analysts continued to express the opinion that the disputed system could pose a threat to Chinese security and be unacceptable to South Korean society. According to one columnist, Zhong Sheng, it is of no use to South Korea as Pyongyang is unlikely to use long-range ballistic missiles. According to this scientist, the US wants to restore its dominant position in Asia by deploying THAAD, which is related to the desire to depreciate China's current position. He also indicates that the installation of the system will accelerate Pyongyang's development of nuclear weapons (Swaine, 2017, p. 6). It was only in November 2017 that the President of South Korea, Moon Jae-in and Xi met during the APEC (Asia-Pacific Economic Community) summit in Vietnam, 
and a month later in Beijing (Beczkowska, 2017), but it is seems obvious that the talks constituted a continuation of vague declarations of mutual cooperation on the Korean issue (Pietrewicz, 2018). The two sides then agreed that under no circumstances could they allow for the outbreak of a military conflict on the Korean Peninsula. It was also established that all available means should be used to de-escalate the existing problems and that in order to successfully solve the problem it will be necessary to improve relations between Koreans (Beczkowska, 2017). This happened two months later, when Kim Jong-un's sister, Kim Yojong, came to the Olympic Games in Pyongyang and the negotiations she made were favourably perceived in Beijing, which clearly supported the negotiations, striving to strengthen its mediation position in the dispute. This support was expressed in three meetings at the Xi-Kim summit between March and June 2018 (Jureńczyk, 2019, p. 16), whereas there were no such contacts with his South Korean counterpart.

In relation to the above, it should be noted that along with further progress in easing the situation on the Korean Peninsula, e.g., Kim's meetings with Moon in April 2018, and the negotiations between President Trump and Kim in Singapore in May of that year, and in Hanoi in February of the following year - it is possible to date a further deterioration of relations between China and South Korea, as Beijing recognized in this situation that the country ruled by Kim Jong-un is an increasingly important entity in a changing international configuration. Moreover, it would be reasonable to suppose that the PRC was counting on a deepening of the divergence between Washington and Seoul as a result of Trump's signalling in Singapore of the possibility of ending joint USSouth Korean exercises. In this context, the words of the South Korean minister for the reunification of Korea, Jeong Se-hyun, who after the above-mentioned summit said that a possible decision on this issue would irreversibly contribute to the deterioration of Washington-Seoul relations (Mencel, 2018a, p. 72). In view of the above, Beijing decided to correct its position on Pyongyang, which was reflected in Xi's visit to North Korea in June 2019. Although during this visit the Chinese side avoided direct accusations against South Korea, it was a signal that China, at the cost of economic contacts with ROK, was willing to re-tighten its ties with its communist neighbour.

However, China continued to follow the denuclearization of the Korean Peninsula and declared together with the Seoul authorities that the removal of the nuclear bomb from the Peninsula was an essential factor in preserving peace. During a meeting between Wang and South Korean National Assembly Chair- 
man Park Byeong-seug in November 2019, a Chinese diplomat said that "ROK and the DPRK are indeed the true masters of the Korean Peninsula. Therefore, the fate of the peninsula should be given to the two countries" (Hussain, 2020). Also a month later, during a meeting in Chengdu of the PRC Prime Minister with the President of South Korea and the Prime Minister of Japan, it was declared that North Korea should end its nuclear program as soon as possible. Prime Minister Li then said openly that representatives of three Asian countries want to overcome tensions on the Peninsula in cooperation with the international community (Historical Agreement of China, 2019). However, we should point out that despite Beijing's declarations and its formal evasion of the dominant role in the Korean dispute, in fact all the most important instruments remain in its discretion. Despite the progressive annoyance at the behaviour of the Kims' regime, Beijing is in fact pleased that it keeps everyone in check, not only its outright opponents, but most of all the antagonists of the Middle Kingdom. The basis for such a statement are the words of one of the Chinese scholars who said about North Korea that "you do not kill a dog that guards our yard so well and bites our enemies so mercilessly" (Dziak, 2018, p. 129). Therefore, it is very likely that China wants to develop such a form of agreement between the Koreas, which would, however, prevent them from establishing an excessively strong alliance between them and at the same time getting closer to the United States (Stuart, 2016, p. 28). One may agree with See-Won Byun's statement that, from the perspective of China's national security, "strategically neutralized" Korea is the optimal scenario because "Beijing's long-term strategic concern is not whether there will be two Koreas or one reunified Korea, but how to reduce U.S. influence there" (Byun, 2020, pp. 155-156). However, at the turn of 2019 and 2020, the Korean problem in relations between Beijing and Seoul receded into the background, and the problem referred to below, has become an increasingly important issue.

This issue, determining contemporary relations between Beijing and Seoul, has become the growing US-Chinese rivalry and South Korea's attitude towards both powers. As a result of $\mathrm{Xi}$ and his acolytes' increasingly assertive rhetoric towards the United States, South Korea, tied to Washington by strategic ties, was put in an awkward position because, on the one hand, it did not want to worsen already strained relations with Beijing, but also could not afford deterioration of contacts with the world's largest power, as it was rightly believed that it was the only guarantor of security for South Korea in the time of a potential conflict with its northern neighbour. 
The situation was further complicated in November 2016 by the election of the Republican Party candidate Donald Trump for the presidency of the United States and the election of Moon Jae-in as president of the country, a supporter of negotiations with North Korea and adopting a more assertive political line towards the United States. Billionaire, sworn in on January 20, 2017 as President of the United States, from the very beginning of his term in office adopted a tough rhetoric towards China, recognizing it not without reason as Washington's main rival on the political and economic levels. Trump also intensified pressure on South Korea, demanding that the country increase its funding for U.S. troops stationed there, and declared that if these demands were not met, he could withdraw them from its territory. The main tenant of the White House was also working to settle the Korean problem and took seriously Kim Jong-un's threats regarding a possible attack on the United States. Trump sustained his desire to build a THAAD system, but demanded that South Koreans increase their financial contributions to the venture and clearly sided with Washington in its confrontation with Beijing.

In view of the complicated relations between Beijing and Seoul, politicians of the latter option tried to avoid unambiguously opting for any of the parties, realizing that a clear bet on the United States without keeping an open path for further negotiations with Beijing would not only worsen the economic situation of the ROK, but it might also ruin the prospects for a solution to the Korean conflict. The internal problems in South Korea itself and the impeachment process of President Park, accused of accepting financial benefits and regular contacts with a fortune teller, who has suggested solutions in important political or economic matters, have undoubtedly contributed to the change in the situation in Sino-South Korean relations, influencing the current decisions of the ruling politician (H.K. Kim, 2016). As a result of her removal from power and sentencing to many years' imprisonment, early presidential elections were held in May 2017, won by the above-mentioned Moon Jae-in. As Joanna Beczkowska points out, Moon refers in his policy to the times when Roh Moo-hyun was in power, who was a supporter of balancing between Washington and Beijing, and Seoul taking over a specific role of an arbitrator in the Far East region (Beczkowska, 2017). In addition, Moon, like other representatives of the South Korean left, are perceived as politicians distanced from the US and more inclined to dialogue with China (Hańderek, 2017). It will be correct to suppose that Moon's election was received in Beijing with the hope that he would be conciliatory about improving relations with the administration in Zhomanghai and that he 
would like to loosen the alliance between South Korea and the USA. However, the actual relations between the two entities did not improve too much, because despite the already known tensions on the Washington-Seoul line, the authorities in the Blue House (the South Korean equivalent of the White House) did not pressurize to sever existing ties with the US or to move closer to China. At the same time, the Chinese communists tried to systematically sow among the South Korean authorities and society the conviction that their alliance with the US was becoming increasingly useless in the face of the easing of the situation on the Korean Peninsula. To this end, the Chinese authorities have increasingly indicated that cooperation between Beijing and Seoul is necessary to strengthen the political and economic area of East Asia, as confirmed by Xi's statement in December 2019 during his meeting with Moon in Beijing that China and South Korea are "influential countries in Asia and the world" and remain "close friends". In turn, Moon, undoubtedly referring to the issue of THAAD, said then that South Korea and China may have a "momentary" feeling of regret towards each other, but they cannot distance themselves from each other (Pak, 2020, p. 5). During the meeting with Minister Wang, he further stated that both countries are neighbours who should strengthen dialogue and cooperation in order to jointly guard multilateralism and free trade. On the other hand, the words of a Chinese politician that China is "opposed to persecution of small nations by large nations who rely only on their potential" (Pak, 2020, p. 6), can be read as an attempt to show the South Korean authorities that the United States in fact "persecute" South Korea and do not want its development at all. Another voice, specifying Beijing's views, was the position of Prime Minister Li Keqiang, who expressed his will to "increase mutual political trust" for the long-term development of mutual relations, noting a rapid growth in trade and a "similar culture" (Byun, 2020, p. 158).

A similar tactic by the Chinese authorities was also continued in the era of the outbreak and spread of the coronavirus pandemic at the turn of 2020. Although the Chinese authorities temporarily had serious problems with controlling this phenomenon, and chairman Xi was criticized by other high party officials for not responding properly in the fight against the disease (Przychodniak, 2020), as a result of the highly drastic measures of quarantine and social self-discipline, the regime in Beijing relatively quickly reduced the number of infections and deaths and thus strengthened its political position at the expense of other countries, especially the United States and Western Europe, which were not warned in time about the already smouldering global threat. The dramatic epidemic situation 
in the US and in Europe made Chinese leaders realize that their authoritarian political model, based on increasing social control, cheap labour and caring for the education of the young generation, is more effective than the one presented by the Western world. They emphasized that only effective cooperation of the Far East countries could contribute to the development of the continent and reduce the American pressure. The above argumentation was directed at Far Eastern entities, including South Korea, which also coped relatively well with subsequent waves of the pandemic. According to South Korea's ambassador to China, Jang Ha-sung, a single country alone cannot overcome a global health crisis such as the ongoing COVID-19 pandemic. To this end, as signalled by the leadership of the CCP, cooperation in the social and economic dimensions between neighbouring countries is crucial (Jie \& Yunyi, 2020).

China's position was expressed in the arrangements made during the telephone conversation between Xi and Moon in January 2021, when the President of the PRC said that China and the Republic of Korea should stick together, that mutual exchange and cooperation in various areas should be promoted, which will bring fruitful results. Xi added that both countries set an example of good cooperation in the fight against the pandemic by presenting appropriate institutional solutions. The Secretary General of the Central Committee of the CCP said in addition that both sides should continue to use the proven mechanism of cooperation, consisting in working out "fast paths" to hinder the spread of the pandemic, intensify its control, and stimulate the economies of both countries, thus supporting regional and, consequently, global development (Xi Jinping Speaks..., 2021). The response from the main tenant of the Blue House was also extremely relevant. Describing the "success" of Beijing in the fight against the COVID-19 pandemic, he pointed out that the Republic of Korea and China have strengthened their friendship and mutual trust precisely through joint efforts in this space, and that his country is ready for a close exchange with China, deepening ties between nations and further promoting cooperation in various areas such as epidemic response, economy, trade, culture, and education. The expression of the Republic of Korea's readiness to continue negotiations with Beijing was the fact that the President appreciated the role of the Middle Kingdom in the process of normalizing climate change and sustainable development. Moon also welcomed Xi's initiative regarding the cultural exchange scheduled for 2022 (Xi Jinping Speaks..., 2021). In a conversation with the new South Korean Foreign Minister in February 2021, Wang suggested that as the current international and regional situation is changing rapidly, both sides should strengthen communi- 
cation and cooperation, implement an important consensus of the two heads of state, and shift the strategic partnership of cooperation between China and South Korea to a higher level (Chinese, South Korean FMs Hold Phone Talks..., 2021). This view was supported by Yu Hongjun, former Deputy Minister of the Department of the International Central Committee of the CPC and Senior Adviser to the Institute for Global Cooperation and Understanding at the Beijing University, who emphasized the importance of maintaining strategic security and stability in Northeast Asia, as well as intensifying the newly developed ways of cooperation in the Korean Peninsula as part of the strategic rivalry between China and the USA. He also proposed the prospect of the future development of this area (China-Korea Policy Academic Conference..., 2020).

Undoubtedly, a lot will also depend on the swearing-in of the US President Joe Biden. It is fair to agree with the analyst Duyeon Kim, who emphasizes that the public and political activists in South Korea, after his election, are relieved in the hope that he will restore a certain degree of predictability, stability and traditional approach to foreign policy (Tiezzi, 2021). Nevertheless, it seems that the new American administration, like the previous one, will continue to expect an increased involvement of South Korea in the course of political affairs in the Far East and the consolidation of support for the US strategy in the Pacific (Pietrewicz, 2019), which may result in the reluctance of the current government in Seoul. It is a realistic scenario that as long as Moon is in charge of the state, South Korea will come closer to Washington to some extent, but will be a country relatively distanced from the Anglo-Saxon power in its fight against China. It is clear that the authorities in Seoul do not want to make an unambiguous choice between Washington and Beijing at the moment, on the assumption that only reaping mutual benefits can contribute to the further evolution of their country.

The situation is not facilitated by divisions among the South Koreans themselves. According to Moon Chung-in of Yonsei University, some research groups in ROK fear intensification of China's power and the possibility of its redomination over Korea known and remembered from earlier periods, while the other group opts for the statement that Seoul should move closer to Beijing at the expense of relations with the USA, because of its potential for global hegemony (Pietrewicz, 2020, p. 240). It is relevant to assume that such a tactic may also be a stalling for time, the more so as China is putting more and more pressure on Seoul, which can be proved by the words of one of the Chinese researchers, Yang Xumeng, who indicates that the most important problem of South Korea at present is making a choice between the USA and the PRC (Li, 2020, p. 47). 
According to Raha Jong-yil, a former South Korean diplomat, China wants to gain any advantage over the United States and, as it were, perceives South Korea as the weak link of the US alliance in Asia (Ryall, 2020). Today, however, no clear changes in the political strategy of Seoul's government circles should be expected.

In this text, we must not forget about South Korea's relations with other East Asian countries, important for Chinese security, i.e., with Japan, Taiwan, and Hong Kong. Upon assuming power, Moon decided that in order to be relatively independent from American and Chinese pressure, it was necessary to create a certain block of East Asian states, based on their political and economic cooperation. Therefore, in November 2017, he announced the "New Southern Policy" strategy (Pietrewicz, 2018). It assumed the strengthening of the strategic ties of South Korea with the Association of Southeast Asian Nations and India, in integrating the cooperation process with other major economies such as China, Japan, and the United States. In contrast, the new northern policy aims to strengthen economic and political ties with the countries neighbouring South Korea (Nan, 2020). Let us emphasize that Moon's intentions and plans encounter serious obstacles. While it can be concluded that the reluctance and distance by China and the ROK towards Japan are still maintained due to the lack of will of the Tokyo authorities to deal with the history of persecution of the Chinese and Korean populations by Japanese troops during World War II, Moon's personal reluctance to participate in the settlement of the Korean conflict - as possible to overcome - it is the Hong Kong and Taiwan issue that is a much bigger problem in relations between Beijing and Seoul. The aggressive rhetoric of the Beijing government and systematic attempts to undermine Hong Kong's autonomy from the beginning of Xi's rule, especially the Act of June 2020, which allowed for a significant limitation of the independence of this still autonomous district, and methodical provocations of the Chinese army off the coast of Taiwan, sparked in South Korea considerable concern of the mass media and the political class, aware that if civil liberties continued to be restricted in Hong Kong and Taiwan, China may again try to undermine Korean statehood and increase the control it had there until the beginning of the $20^{\text {th }}$ century. Although the words of the Chinese ambassador to South Korea, Xing Haiming, in May 2020, softened the image of Chinese actions and emphasized that the Chinese side would actively communicate with Seoul on Hong Kong law, hoping to obtain "understanding and support" from the Korean side (Kang, 2020), it is remarkably meaningful that the Pew Research Center poll of October 2020 showed that $83 \%$ of South Koreans are unsure that $\mathrm{Xi}$ is pursuing a reasonable policy, and $75 \%$ have 
a negative attitude towards China, which is a significant difference compared to a corresponding survey in 2002, when less than a third of citizens spoke ill of China (Ch.M. Lee, 2020). It is reasonable to suppose that the above data were received in Zhomanghai with some concern that the South Korean society may pressure its authorities to be more strict towards the Asian power.

It should be added that the South Korean authorities are trying to avoid the subject of Hong Kong in public. It is significant that during Moon's visit to China in December 2019, the Ministry of Foreign Affairs of the PRC quoted his position that "Hong Kong matters and Xinjiang issues are among China's internal affairs". The office of the South Korean President did not include the statement in its summit briefing (Byun, 2020, p. 164). The above suggests that Seoul will not be too critical in its policy towards China considering exacerbation of the Chinese regime, being aware of the influence of this state on the Korean problem, its growing role in the global economic system, and the poor relations between Seoul and Washington, and successful development of the entire Asian continent. Such progress is expressed in the economic cooperation of the countries of the Southeast Asia region, as it is referred to below.

\section{ECONOMIC RELATIONS BETWEEN BEIJING AND SEOUL}

In this text, we should not ignore the economic contacts of entities of particular interest to us. In 2014, China's course of trade with South Korea was higher than with Japan, the USA, or the EU (Ye, 2017, p. 7). China's economic slowdown also meant a decline in exports from the Republic of Korea to China that year by $8.8 \%$ in the period from January to August compared to the same period of the previous year, and such a continuing trend resulted in a decline in GDP growth in South Korea also in 2015 from about 3\% to about 2\%. While total of South Korea's foreign direct investment increased by $12.1 \%$ in the January-June period, the percentage of Chinese investment in Korea decreased by as much as 32.1\% (Snyder \& Byun, 2013, p. 105). In 2016, trade between the two was over $\$ 210$ billion, and Beijing was the largest partner in both exports and imports (25\% and 20\%, respectively). From the Chinese perspective, South Korea was the largest source of imports and the third market (10\% and $4 \%$, respectively) (Pietrewicz, 2018). Until the 2016 THAAD dispute, part of the China-ROK trade in its overall picture of the foreign turnover of the Chinese economy since 1996 has fluctuated around 7-8\% (Byun, 2020, p. 156). After the crisis, however, there 
were restrictions on Beijing, expressed by a ban on the export of its goods to China for nineteen Korean companies (Trzcińska, 2019, p. 68), and a decrease in the number of Chinese tourists by almost a half in the period from January to September 2017 did not inhibit the overall trade, which increased by $10 \%$ (Pietrewicz, 2018).

The tensions gradually eased, but according to Moon, China’s "economic retaliation" measures cost the South Korean economy $\$ 8$ billion (Byun, 2020, p. 161). As the THAAD dispute was eased, both sides concluded that a more pragmatic economic policy would be needed. It is possible that this was also influenced by the position of Chinese consumers, who, according to KITA (Korean International Trade Association) data in December 2017, viewed Korean consumer goods very positively, especially in terms of quality and design (J.Y. Lee et al., 2020, p. 12). As a result, in 2018 China's trade with South Korea already amounted to $\$ 313$ billion (Paszak, 2020), containing a large percentage of high-tech products (Chung, 2015, p. 604). The efforts of the Koreans for their own economic independence create a certain reluctance of the rulers to too far-reaching economic cooperation with China (M.H. Kim, 2016, p. 721), while still emphasizing the need to maintain pragmatism in mutual economic relations.

As a result of the coronavirus pandemic, bilateral trade decreased by $2.6 \%$ per year (Nan, 2020), but both countries concluded that this state can and should contribute to the intensification of cooperation between Asian countries. This message was expressed in the more intensive participation of both countries in the Asian Infrastructure Investment Bank. The institution established in 2016 aims to improve infrastructure in Asia and to act in the fields of energy, transport and logistics in rural and urban areas (Hsu, 2018, p. 54). Regular meetings of the members of the Association of Southeast Asian Nations (ASEAN) were also important, with the leaders of China, South Korea and Japan attending alongside the leaders of the signatory countries. In the post-2020 summit document, we read that in the era of the fight against COVID-19, it is necessary to maintain open markets, a free, fair, non-discriminatory and equitable trading environment, taking into account national laws and regulations, the sustainability of regional supply chains, the necessary flow of basic goods and services, as well as to ensure and maintain the basic flow of people and goods for diplomatic, humanitarian, scientific and business activities (Chairman's Statement..., 2020, p. 3). According to the aforementioned Chinese ambassador to South Korea, Jang Ha-sung, due to the epidemic, both countries have introduced an "accelerated procedure" that alleviates obstacles for entrepreneurs in order to guarantee the 
necessary continuation of business activity. Since the beginning of May 2020, when they started using this procedure, more than 10,000 people from the business community have already travelled between Korea and China (Jie \& Yunyi, 2020). A few months later, in November, China and South Korea, along with thirteen other Asian countries and the Pacific, signed a Regional Comprehensive Economic Partnership, the largest-ever free trade agreement that covers 30\% of the world's population and economic production (RCEP..., 2020). However, the correct view will be that economic cooperation between South Korea and China may be more difficult in the future if the political relations of both of these entities are not transformed (Ye, 2016, p. 116).

\section{CONCLUSION}

To sum up these considerations, in the near future we should expect the continuation of the existing relations between Beijing and Seoul, but much will depend on the US position on the Korean problem, the course of its rivalry with China, the issue of overcoming the coronavirus pandemic in the United States, the attitude of the Chinese authorities and the approaching presidential elections in South Korea. There is no doubt that in the event of a possible re-election of Moon or the election of one of his supporters as president, one should expect even greater distance from the United States of Seoul and attempts at rapprochement with China. In turn, if his successor derives from the conservative camp, he may adopt a more pro-American course, which will lead to a deterioration in Sino-South Korean relations. Many South Korean analysts and international policy observers may not fully appreciate the fact that the weakening of the Washington-Seoul alliance may not only push the ROK into Beijing's orbit, putting its security to a test that could prove costly and hard to reverse. It is true that the war on the Korean Peninsula is very unlikely in the current circumstances, mainly due to the reluctance of each of its potential participants to undertake such actions and the imminent reunification of the Peninsula, but in the event of a weakening of the US military contingent in South Korea, it cannot be ruled out there is a scenario that the North Korean side may increase the frequency of subversive actions in the territory of its southern neighbour, aimed at undermining the democratic foundations of the society of the Republic of Korea and destabilizing from within the country's political system. Therefore, it seems more likely that the strategic relations between Washington and Seoul will be maintained, but 
they will be determined by the degree of commitment to supporting the actions of the Washington administration and the very provenance of this government. Regardless of the possible configuration of power in the Republic of Korea, China will treat this country as an ally of the United States for a long time, which may increase suspicion and distrust towards it, and will probably not improve mutual relations on the political level.

\section{REFERENCES:}

Beczkowska, J. (2017, December 20). Korea Południowa i Chiny w „nowej erze”. Retrieved from: http://osa.uni.lodz.pl/?p=8114.

Byun, S.W. (2020). Chinese Views of South Korea: Aligning Elite and Popular Debates. Joint U.S.-Korea Academic Studies, 23, 154-169. Retrieved from:

http://www.keia.org/sites/default/files/publications/kei_jointus-korea_2020_2.3.pdf. Chairman's Statement of the $23^{\text {rd }}$ ASEAN Plus Three Summit, Viet Nam, 14 November 2020 (2020). Retrieved from: https://www.mofa.go.jp/files/100117712.pdf.

Chinese, South Korean FMs Hold Phone Talks on Bilateral Ties, Korean Peninsula Issue (2021, February 17). Retrieved from:

http://english.www.gov.cn/statecouncil/wangyi/202102/17/content_WS602c55eec6d0719374af8eb1.html.

China-Korea Policy Academic Conference Held for Seventh Consecutive Year - Over 20 Scholars from China and South Korea Engage in Heated Discussion of "Changes in the Global Order and China-Korea Relations" (2020, November 13). Retrieved from: http://en.igcu.pku.edu.cn/info/1014/2147.htm.

Chung, A. (2015). Effects of Trade Relations on South Korean Views of China. Asian Politics \& Policy, 7(4), 597-621. DOI: 10.1111/aspp.12218.

Dziak, W. (2018). Anatomia władzy totalnej. Przypadek Korei Pótnocnej. Warszawa: Wydawnictwo Instytutu Studiów Politycznych PAN.

Dziak, W., \& Bayer, J. (2006). Korea \& Chiny. Vol. 1: Strategia i polityka. Warszawa: Wydawnictwo Instytutu Studiów Politycznych PAN.

Fifield, A. (2020). Wielki Następca. Niebiańskie przeznaczenie blyskotliwego towarzysza Kim Dzong Una. Kraków: Wydawnictwo SQN.

Hańderek, M. (2017, August 17). Główne kierunki polityki zagranicznej i bezpieczeństwa nowego prezydenta Korei Południowej. Retrieved from: http://www.polska-azja. $\mathrm{pl} / 212848-2 /$.

Historyczne porozumienie Chin, Korei Płd. i Japonii. Chca zakończyć program nuklearny Korei Ptn. (2019, December 24). Retrieved from:

https://www.polskieradio24.pl/5/1223/Artykul/2427287, Historyczne-porozumienieChin-Korei-Pld-i-Japonii-Chca-zakonczyc-program-nuklearny-Korei-Pln.

Ho, Ch.J. (2018). South Korea's Strategic Approach to China (or Lack of It). Joint U.S.-Korea Academic Studies, 29, 72-90. Retrieved from: 
https://215sw4qvcho3x9qjb2g5qybp-wpengine.netdna-ssl.com/wp-content/ uploads/2020/05/kei_jointus-korea_2018_180801_final_digital.pdf.

Hoshino, M., \& Hiraiwa, S. (2020). Four Factors in the "Special Relationship" between China and North Korea: A Framework for Analyzing the China-North Korea Relationship under Xi Jinping and Kim Jong-un. Journal of Contemporary East Asia Studies, 9(1), 18-28. DOI: 10.1080/24761028.2020.1754998.

Hsu, S. (2018). Viability of Asian Infrastructure Investment Bank's Financials and Objectives. In: A. Ehteshami, \& N. Horesh (Eds.). China Presence in the Middle East: The Implications of the One Belt, One Road Initiative (pp. 54-64). London: Routledge. Hussain, H. (2020, November 28). China, South Korea Relations Move from Strength to Strength. Retrieved from: https://news.cgtn.com/news/2020-11-28/China-SouthKorea-relations-move-from-strength-to-strength-VMNC7jY1PO/index.html.

Jie, S., \& Yunyi, B. (2020, December 7). China-South Korea Cooperation in Health, Peopleto-People Exchange a Model to the World: South Korean Ambassador. Retrieved from: https://www.globaltimes.cn/content/1209229.shtml.

Jin, P. (2015). Korea Between the United States and China: How Does Hedging Work? Joint U.S.-Korea Academic Studies, 26, 59-73. Retrieved from: https://215sw4qvcho3x9qjb2g5qybp-wpengine.netdna-ssl.com/wp-content/ uploads/2020/05/kei_jointus-korea_2015_final_lowres.pdf.

Jureńczyk, Ł. (2019). Międzynarodowe uwarunkowania postawy Chińskiej Republiki Ludowej wobec programu nuklearnego Koreańskiej Republiki LudowoDemokratycznej w XXI wieku. Roczniki Humanistyczne, 67(9), 5-36.

Kang, T.J. (2020, May 29). On Hong Kong, South Korea Is Caught between China and US. Retrieved from: https://thediplomat.com/2020/05/on-hong-kong-south-korea-iscaught-between-china-and-us/.

Kim, H.K. (2016). Out of the Shadows: The Collapse of Park Geun-hye and the Future of South Korea. GlobalAsia, 11(4). Retrieved from: https://www.globalasia.org/ v11no4/feature/out-of-the-shadows-the-collapse-of-park-geun-hye-and-thefuture-of-south-korea_ho-ki-kim.

Kim, M.H. (2016). South Korea’s Strategy toward a Rising China, Security Dynamics in East Asia, and International Relations Theory. Asian Survey, 56(4), 707-730. DOI: 10.1525/AS.2016.56.4.707.

Kim, I.J. (1998). Korea's Relations with China and Japan in the Post-Cold War Era. International Journal of Korean Studies, 2(1), 27-44.

„Konflikt nie leży $w$ naszym interesie”. Odwilż $w$ relacjach Chin $z$ Korea Południowa (2017, November 17). Retrieved from: https://tvn24.pl/swiat/pekin-spotkanieszefow-dyplomacji-chin-i-korei-poludniowej-ra792549-2574701.

Lee, Ch.M. (2020, October 21). South Korea Is Caught between China and the United States. Retrieved from:

https://carnegieendowment.org/2020/10/21/south-korea-is-caught-between-chinaand-united-states-pub-83019. 
Lee, J.Y. (2020). The Geopolitics of South Korea-China Relations: Implications for U.S. Policy in the Indo-Pacific, pp. 1-28. Retrieved from: https://www.rand.org/ content/dam/rand/pubs/perspectives/PEA500/PEA524-1/RAND_PEA524-1.pdf.

Lee, J.Y., Kim, J.I., Jiménez, A., \& Biraglia, A. (2020). The Role of Subnational Cultural Value on Animosity: The China-South Korea THAAD Crisis. Cross Cultural and Strategic Management, 28(2), 1-46. DOI: 10.1108/CCSM-01-2020-0010.

Li, Y. (2020). China and South Korea Diplomatic Relations Present Status and Perspectives. Modern Economics \& Management Forum, 1(1), 44-49. DOI: 10.32629/memf. vli1.123.

Mencel, M.T. (2018a). Denuclearisation of the Korean Peninsula: Consequences of the Meeting between Donald Trump and Kim Jong Un in Singapore 12 June 2018. Przegląd Nauk o Obronności, 3(6), 61-79. DOI: 10.37055/pno/118882.

Mencel, M. (2018b). Konsekwencje spotkania Donalda Trumpa i Kim Dzong Una w Singapurze. Studia Gdańskie. Wizje i rzeczywistość, 15, 33-59. DOI: 10.5604/01.3001.0014.0395.

Nan, Z. (2020, August 4). China, South Korea Step Up Economic Ties. Retrieved from: http://english.www.gov.cn/news/internationalexchanges/202008/04/content_ WS5f28bb58c6d029c1c26372a4.html.

Pak, J.H. (2020). Trying to Loosen the Linchpin: China's Approach to South Korea. In: Chhabra, T., Doshi, R., Hass, R., \& Kimball, E. (Eds.). Global China: Assessing China's Growing Role in the World [online edition], pp. 1-15. Retrieved from: https://www. brookings.edu/wp-content/uploads/2020/07/FP_20200606_china_south_korea_ pak_v2.pdf.

Paszak, P. (2020, September 11). Dyplomacja Xi Jinpinga 2013-2020. Retrieved from: https://ine.org.pl/dyplomacja-xi-jinpinga-2013-2020/.

Pietrewicz, O. (2018, January 5). Stosunki Chiny-Korea Południowa: próba wyjścia z impasu. Biuletyn PISM, 3. Retrieved from: https://pism.pl/publikacje/Stosunki_ Chiny__Korea_Po_udniowa_pr_ba_wyj_cia_z_impasu.

Pietrewicz, O. (2019, October 15). Wyzwania sojuszu USA-Korea Południowa. Biuletyn PISM, 143. Retrieved from: https://pism.pl/publikacje/Wyzwania_sojuszu_USA_ Korea_Poludniowa.

Pietrewicz, O. (2020). Krewetka między wielorybami. Pótwysep Koreański w polityce mocarstw. Warszawa: Wydawnictwo Asian Century.

Przychodniak, M. (2020, April 2). Znaczenie pandemii COVID-19 dla sytuacji wewnętrznej i polityki zagranicznej Chin. Biuletyn PISM, 64. Retrieved from: https://pism.pl/publikacje/Znaczenie_pandemii_COVID19_dla_sytuacji_ wewnetrznej_i_polityki_zagranicznej_Chin.

RCEP: Asia-Pacific Countries Form World's Largest Trading Bloc (2020, November 16). Retrieved from: https://www.bbc.com/news/world-asia-54949260.

Renner, L.Y. (2006, March). The Growing Relationship between South Korea and China: Consequences for North Korea, pp. 1-129. Master's Thesis. Naval Postgraduate School. Retrieved from: https://apps.dtic.mil/dtic/tr/fulltext/u2/a445560.pdf. 
Roszkowski, W. (2005). Pótwiecze. Historia polityczna świata po 1945 roku. Warszawa: Wydawnictwo Naukowe PWN.

Ryall, J. (2020, October 6). South Korea Struggles to Choose between US and China. Retrieved from: https://www.dw.com/en/south-korea-struggles-to-choosebetween-us-and-china/a-55172936.

Snyder, S., \& Byun, S.W. (2009). The Obama Administration and Preparations for North Korean Instability. International Journal of Korean Unification Studies, 18(2), 1-29. Snyder, S., \& Byun, S.W. (2013). China-Korea Relations: How Does China Solve a Problem Like North Korea? Comparative Connections, 15(2), 97-109.

Snyder, S., Byun S.W. (2013). China-Korea Relations: Under New Leaderships. Comparative Connections, 14(3), 97-106.

Strnad, G. (2014). Korea. Polityka Południa wobec Północy w latach 1948-2008. Zmiana i kontynuacja. Poznań: Instytut Zachodni.

Stuart, D.T. (2016). The Pivot to Asia: Can It Serve as the Foundation for American Grand Strategy in the $21^{\text {st }}$ Century? Washington: Lulu.com, Strategic Studies Institute.

Swaine, M. (2017). Chinese Views on South Korea's Deployment of THAAD. China Leadership Monitor, 52(4), 1-15.

Tiezzi, S. (2021, February 2). Duyeon Kim on South Korea's Foreign Policy Priorities. Retrieved from: https://thediplomat.com/2021/02/duyeon-kim-on-south-koreasforeign-policy-priorities/.

Trzcińska, J. (2019). Skuteczność stosowania soft power Republiki Korei w Japonii i w Chinach. Athenaeum. Polskie Studia Politologiczne, 61(1), 58-73. DOI: 10.15804/ athena.2019.61.04.

Xi Jinping Speaks with ROK's President Moon Jae-in on the Phone (2021, January 26). Retrieved from: https://www.fmprc.gov.cn/ce/cepl/pol/zgyw/t1848911.htm.

Ye, M. (2016). Understanding the Economics-Politics Nexus in South KoreaChina Relations. Journal of Asian and African Studies, 51(1), 97-118. DOI: $10.1177 / 0021909615585179$.

Ye, M. (2017). China-South Korea Relations in the New Era: Challenges and Opportunities. Lanham, MD: Lexington Books.

Yi, X. (2002). Ten Years of China-South Korea Relations and Beijing's View on Korean Reunification. The Journal of East Asian Affairs, 16(2), 315-351. 